\title{
PROCESS DESIGN OF ETHANOL REFORMING FOR HYDROGEN PRODUCTION
}

\author{
Alan M. Avelar \\ Bruno L. Augusto ${ }^{2}$ \\ Luiz C.T. Lima $^{3}$ \\ Jorge E.S. Ourique
}

\begin{abstract}
The use of hydrogen in fuel cells is considered by many researchers one of the most convenient methods for electric energy production, under environmentally. Hydrogen can be obtained from water or organic sources, among which are natural gas, petroleum naphtha and methanol. However, ethanol presents a great number of advantages over fossil fuels, because it is produced from renewable biomass, therefore almost neutral in terms of carbon dioxide $\left(\mathrm{CO}_{2}\right)$ emissions. Furthermore, it provides ease handling and storage, and less toxicity when compared to other organic sources. In this project, the process development was conducted through the following steps: modeling and simulation of reactive systems, with kinetics obtained from technical papers, adjustment of operational variables and analysis of the process efficiency.
\end{abstract}

\section{INTRODUCTION}

Among the alternative sources for energy production, hydrogen $\left(\mathrm{H}_{2}\right)$ deserves great attention. The use of hydrogen in fuel cells for electric energy generation is shown as a clean and efficient energy source. (Camargo, 2004)

In this context, the hydrogen production from ethanol obtained from renewable biomass fermentation has been considered, since this process is capable to solve two key issues: reducing the dependence on fossil fuels (oil and natural gas) and non-contributing to increase the emissions of carbon dioxide in the atmosphere, because the generated $\mathrm{CO}_{2}$ is consumed during the growth of sugar cane. (Andrade, 2007)

The development of a process route for ethanol steam reforming is based on studies on similar industrial processes, and new scientific techniques. This step aims to assess the conditions under which the process is viable in a technical point of view.

The block diagram of the process involves three steps: Steam Reforming, the Water-GasShift reaction and Selective Oxidation of Carbon Monoxide (SELOX).

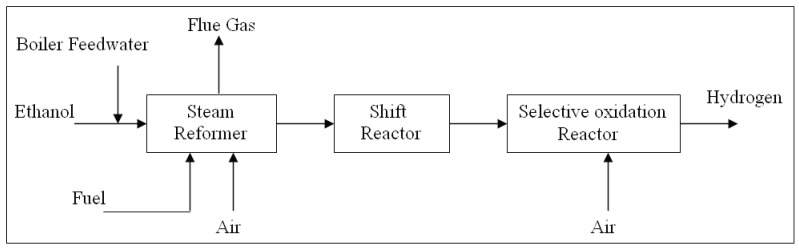

Figure 1 - Block diagram proposed for ethanol steam reforming process.

\section{MODELING AND SIMULATION}

As the process occurs in vapour phase and the operating pressures are relatively low, its not expected high deviations from ideality. Therefore, the thermodynamic package used in the simulations was the PRSV (Peng-Robinson Stryjek-Vera), which extends the application of the PengRobinson equation to moderately non-ideal systems.

The process comprises two major sections: steam reforming and product purification. The raw material used is $50 \%$ ethanol (volume), because it provides good hydrogen production, with a water/ethanol molar ratio that doesn't demand high energy expenditure for vaporization; and

\footnotetext{
1 Universidade Federal Fluminense, Departamento de Engenharia Química. e-mail: aolbr_mail@yahoo.com.br

2 Universidade Federal Fluminense, Departamento de Engenharia Química. e-mail: brunolobatoaugusto@hotmail.com

3 Universidade Federal Fluminense, Departamento de Engenharia Química. e-mail: lct_lima@yahoo.com.br

${ }^{4}$ Universidade Federal Fluminense, Departamento de Engenharia Química. e-mail: jeourique@gmail.com
} 
also contributes to energy saving while avoiding azeotropic distillation, that is usually made with solvents for anhydrous ethanol production.

Natural gas is used as fuel in the steam reformer because it has a high net calorific value and easy availability due to its distribution network. Operating temperatures are selected to ensure a good production of hydrogen with low methane content. The temperature evaluation was possible through a chemical equilibrium analysis of the reactions coordinates. As the fuel cell operates at $4.5 \mathrm{bar}$, the operating pressure should be able to overcome head losses in the process so as to ensure the hydrogen feed pressure in the fuel cell. The effect of the operating pressure in the chemical equilibrium is also evaluated.

The final product must meet the requirements for the supply in PEMFC. The maximum concentration of carbon monoxide is $10 \mathrm{ppm}$. The unit is compact and has a nominal capacity of $36 \mathrm{gmol} / \mathrm{h}$ of hydrogen.

\subsection{STEAM REFORMING SECTION}

The steam reforming section consists of a steam reformer furnace/reactor, which is the main equipment of the unit. The reformer has several functions: to vaporize and superheat the feed, and perform the reaction in a fixed bed in order to produce hydrogen. The proposed kinetic route has the following pathway: First, ethanol decomposes into methane according to the following reaction:

$\underset{\mathrm{kJ} / \mathrm{mol}}{\mathrm{C}_{2} \mathrm{H}_{5} \mathrm{OH}_{(\mathrm{v})}} \longleftrightarrow \mathrm{CH}_{4(\mathrm{~g})}+\mathrm{CO}_{(\mathrm{g})}+\mathrm{H}_{2(\mathrm{~g})} \Delta \mathrm{H}=49$

This reaction is fast and complete, and also generates hydrogen as a product. Then, methane reacts with steam generating more hydrogen as follows:

$\mathrm{CH}_{4(\mathrm{~g})}+\mathrm{H}_{2} \mathrm{O}_{(\mathrm{v})} \longleftrightarrow \mathrm{CO}_{(\mathrm{g})}+3 \mathrm{H}_{2(\mathrm{~g})} \Delta \mathrm{H}=206$ $\mathrm{kJ} / \mathrm{mol}$

The water-gas-shift reaction below also occurs inside the reformer, but in small amounts due its high operating temperature.

$\underset{\mathrm{mol}}{\mathrm{CO}_{(\mathrm{g})}}+\mathrm{H}_{2} \mathrm{O}_{(\mathrm{v})} \longleftrightarrow \mathrm{H}_{2(\mathrm{~g})}+\mathrm{CO}_{2(\mathrm{~g})} \Delta \mathrm{H}=-41 \mathrm{~kJ} /$
The reaction system is predominantly endothermic and therefore it is necessary to provide heat so as to ensure good yield to the process. Heat is supplied by burning natural gas.

The reformer model is based on the equations proposed by Davies and Lihou (1971) and Amadeo et al. (2008), who used the LangmuirHinshelwood model to describe heterogeneous kinetics. According to this mechanism, the reactions occur only on the catalyst surface and not in the vapour phase. The rate of ethanol decomposition reaction and its kinetics parameters are described below:

$$
\begin{aligned}
& r_{1}=\frac{k_{1} \cdot K_{\mathrm{C}_{2} \mathrm{H}_{5} \mathrm{OH}} \cdot P_{\mathrm{C}_{2} \mathrm{OH}}}{1+P_{\mathrm{C}_{2} \mathrm{H}_{5} \mathrm{OH}} \cdot K_{\mathrm{C}_{2} \mathrm{H}_{5} \mathrm{OH}}+P_{\mathrm{H}_{2} \mathrm{O}} \cdot K_{\mathrm{H}_{2} \mathrm{O}}+P_{\mathrm{CH}_{4}} \cdot K_{\mathrm{CH}_{4}}} \\
& k_{1} \cdot K_{\mathrm{C}_{2} \mathrm{H}_{5} \mathrm{OH}}=A_{a p} \cdot \exp \left(-E_{a p} /(8,314 \cdot T)\right)
\end{aligned}
$$

Table 1 - Kinetic parameters for the ethanol decomposition reaction in the reformer at $873 \mathrm{~K}$. Amadeo et al. (2008)

\begin{tabular}{|c|}
\hline $\mathrm{E}_{1}=278740 \mathrm{~J} / \mathrm{gmol}$ \\
\hline $\mathrm{k}_{1}=2,9.10^{-5}(\mathrm{gmol}) /(\mathrm{min} \cdot \mathrm{mg})$ \\
\hline $\mathrm{K}_{C_{2} \mathrm{H}_{5} \mathrm{OH}}=61,7 \mathrm{bar}^{-1}$ \\
\hline $\mathrm{K}_{\mathrm{H}_{2} \mathrm{O}}=37,4 \mathrm{bar}^{-1}$ \\
\hline $\mathrm{K}_{\mathrm{CH}_{4}}=1135 \mathrm{bar}^{-1}$ \\
\hline$\Delta \mathrm{H}_{\mathrm{C}_{2} \mathrm{H}_{5} \mathrm{OH}}=-199700 \mathrm{~J} / \mathrm{mol}$ \\
\hline$\Delta \mathrm{H}_{\mathrm{H}_{2} \mathrm{O}}=-92400 \mathrm{~J} / \mathrm{mol}$ \\
\hline$\Delta \mathrm{H}_{\mathrm{CH}_{4}}=-124700 \mathrm{~J} / \mathrm{mol}$ \\
\hline
\end{tabular}

The rates for methane steam reforming and water-gas-shift, $\mathrm{r} 2$ and $\mathrm{r} 3$ respectively, are described below.

$r_{2}=\frac{\frac{k_{2}}{P_{\mathrm{H}_{2}}^{2,5}} \cdot\left(P_{\mathrm{CH}_{4}} \cdot P_{\mathrm{H}_{2} \mathrm{O}}-\frac{P_{\mathrm{H}_{2}}^{3} \cdot P_{\mathrm{CO}}}{K e q_{2}}\right)}{\left(1+P_{\mathrm{CO}} \cdot K_{\mathrm{CO}}+P_{\mathrm{H}_{2}} \cdot K_{\mathrm{H}_{2}}+P_{\mathrm{CH}_{4}} \cdot K_{\mathrm{CH}_{4}}+\frac{P_{\mathrm{H}_{2} \mathrm{O}} \cdot K_{\mathrm{H}_{2} \mathrm{O}}}{P_{\mathrm{H}_{2}}}\right)^{2}}$

$K e q_{2}=1,026676 \cdot \exp (-26830 / T+30,11)$

$\mathrm{Keq}_{3}=\exp (4400 / T-4,063)$ 
Table 2 contains the values of the kinetic parameters used in the calculations of the methane steam reforming and water-gas-shift reactions. The effectiveness factors are 0.02 and 0.015 respectively.

Table 2 - Kinetic parameters for the methane reforming and water gas shift reactions at $973 \mathrm{~K}$.

Davies and Lihou (1971)

\begin{tabular}{|c|}
\hline$\rho_{\text {cat }}=2355,2 \mathrm{~kg} / \mathrm{m}^{3}$ \\
\hline $\mathrm{E}_{2}=240100 \mathrm{~J} / \mathrm{gmol}$ \\
\hline $\mathrm{E}_{3}=67130 \mathrm{~J} / \mathrm{gmol}$ \\
\hline $\mathrm{k}_{2}=12877\left(\mathrm{kgmol} \cdot \mathrm{bar}^{0,5}\right) /\left(\mathrm{m}^{3} \cdot \mathrm{h}\right)$ \\
\hline $\mathrm{k}_{3}=8606\left(\mathrm{kgmol} / \mathrm{bar} \cdot \mathrm{m}^{3} \cdot \mathrm{h}\right)$ \\
\hline $\mathrm{A}\left(K_{C O}\right)=8,23.10^{-5} \mathrm{bar}^{-1}$ \\
\hline $\mathrm{A}\left(K_{\mathrm{H}_{2}}\right)=6,12.10^{-9} \mathrm{bar}^{-1}$ \\
\hline $\mathrm{A}\left(K_{\mathrm{CH}_{4}}\right)=6,65.10^{-4} \mathrm{bar}^{-1}$ \\
\hline $\left.\mathrm{A}_{\left(K_{H_{2} O}\right.}\right)=1,77.10^{5}$ \\
\hline$\Delta \mathrm{H}_{\mathrm{CO}}=-70650 \mathrm{~J} / \mathrm{gmol}$ \\
\hline$\Delta \mathrm{H}_{H_{2}}=-82900 \mathrm{~J} / \mathrm{gmol}$ \\
\hline$\Delta \mathrm{H}_{\mathrm{CH}_{4}}=-38280 \mathrm{~J} / \mathrm{gmol}$ \\
\hline$\Delta \mathrm{H}_{H_{2} O}=88680 \mathrm{~J} / \mathrm{gmol}$ \\
\hline
\end{tabular}

The concentrations profile along the reactor was obtained solving the mass balance. The results are shown in Figure 2.

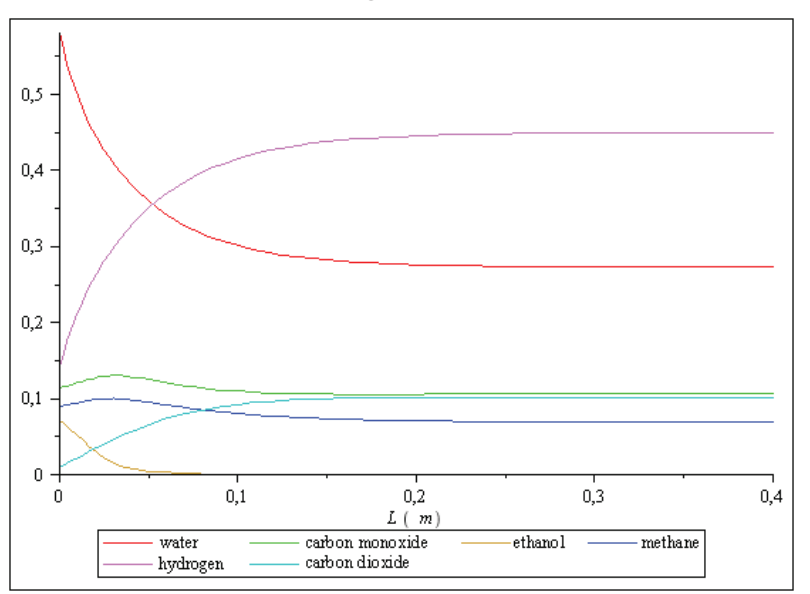

Figure 2 - Components mole fractions profiles along the reactor. Feed: ethanol 50\% (volume); operational conditions are $700^{\circ} \mathrm{C}$ and $5 \mathrm{bar}$

\subsection{PURIFICATION SECTION}

Only one shift reactor was used in order to decrease the size of the unit. This reactor operates at $250^{\circ} \mathrm{C}$, which is a middle-term value between the operating temperatures of high and low temperature water-gas-shift reactors (RostrupNielsen, 2002).

The water-gas-shift reaction rate is calculated through the following equations: (RostrupNielsen, 2002)

$$
\begin{aligned}
& r_{4}=k_{4} \cdot C_{C O}^{n} \cdot C_{\mathrm{H}_{2} \mathrm{O}}^{m} \cdot C_{\mathrm{O}_{2}}^{p} \cdot C_{\mathrm{H}_{2}}^{q} \cdot(1-\beta) \\
& \beta=\frac{C_{\mathrm{CO}_{2}} \cdot C_{\mathrm{H}_{2}}}{C_{\mathrm{CO}_{2} \cdot C_{\mathrm{H}_{2} \mathrm{O}} \cdot \mathrm{Keq}_{3}}}(8)
\end{aligned}
$$

The exponents may be different for each catalyst. The kinetic parameters shown in Table 3 were developed by Georgopoulous (2002).

Table 3 - Kinetic parameters of the water gas shift reactor. Georgopoulous (2002)

\begin{tabular}{|c|}
\hline $\mathrm{m}=0,15$ \\
\hline $\mathrm{n}=0,78$ \\
\hline $\mathrm{A}_{4}=131,93\left(\mathrm{kgmol}^{0,07} \cdot \mathrm{m}^{2,79}\right) /(\mathrm{kg} \cdot \mathrm{s})$ \\
\hline$\rho_{\text {cat }}=1400 \mathrm{~kg} / \mathrm{m}^{3}$ \\
\hline $\mathrm{E}_{4}=42620 \mathrm{~J} / \mathrm{gmol}$ \\
\hline
\end{tabular}

The concentrations profile along the reactor was obtained solving the mass balance. The results are shown in Figure 3.

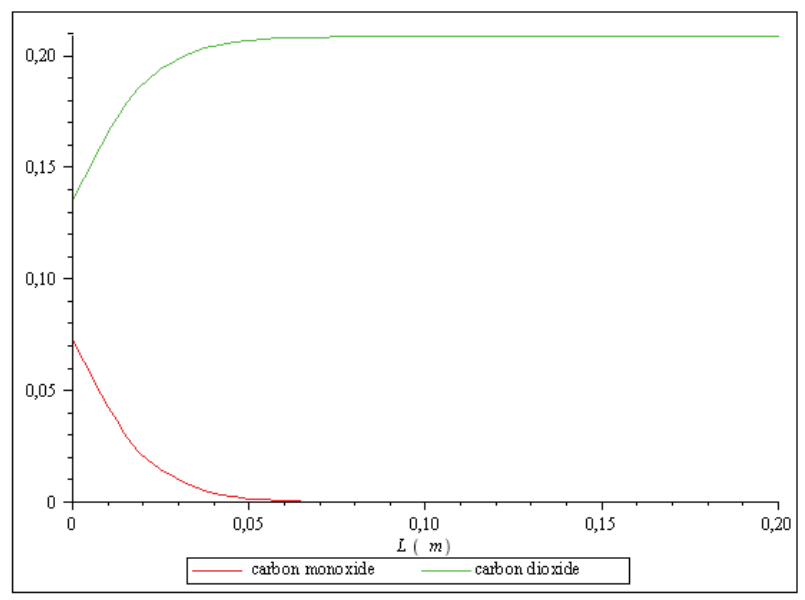

Figure 3 - Components mole fractions profiles along the water-gas-shift reactor 
Three reactions take place in the selective oxidation reactor: oxidation of carbon monoxide (desirable), oxidation of hydrogen (undesirable) and reverse water gas shift (undesirable).

$$
\begin{aligned}
& \mathrm{CO}_{(\mathrm{g})}+1 / 2 \mathrm{O}_{2(\mathrm{~g})} \longrightarrow \mathrm{CO}_{2(\mathrm{~g})} \\
& \mathrm{H}_{2(\mathrm{~g})}+1 / 2 \mathrm{O}_{2(\mathrm{~g})} \longrightarrow \mathrm{H}_{2} \mathrm{O}_{(\mathrm{v})} \\
& \mathrm{H}_{2(\mathrm{~g})}+\mathrm{CO}_{2(\mathrm{~g})} \longleftrightarrow \mathrm{CO}_{(\mathrm{g})}+\mathrm{H}_{2} \mathrm{O}_{(\mathrm{v})}
\end{aligned}
$$

The kinetic model used for the selective oxidation reactor is a simplified homogeneous approach for the three reactions, where only the reverse water gas shift reaction is considered reversible. The reactions rate equations and kinetic parameters are given bellow:

$$
\begin{aligned}
& r_{5}=k_{5} \cdot P_{O_{2}}^{0,5} P_{C O}^{-0,1} \\
& r_{6}=k_{6} \cdot P_{O_{2}}^{0,5}(10) \\
& r_{7}=k_{7} \cdot\left(P_{C O} P_{H_{2} O}-\frac{P_{C O_{2}} P_{H_{2}}}{K_{e q}}\right) \\
& K_{e q}=\exp \left(\frac{4577,8}{T}-4,33\right)(12)
\end{aligned}
$$

Table 4 - Kinetic parameters of Selective Oxidation Reactor

\begin{tabular}{|c|}
\hline $\mathrm{E}_{5}=33092 \mathrm{~J} / \mathrm{gmol}$ \\
\hline $\mathrm{A}_{5}=352,8(\mathrm{gmol}) /\left(\mathrm{bar}^{0,4} \cdot \mathrm{g} \cdot \mathrm{h}\right)$ \\
\hline $\mathrm{E}_{6}=18742 \mathrm{~J} / \mathrm{gmol}^{0}$ \\
\hline $\mathrm{A}_{6}=20,53(\mathrm{gmol}) /\left(\mathrm{bar}^{0,5} \cdot \mathrm{g} \cdot \mathrm{h}\right)$ \\
\hline $\mathrm{A}_{7}=4402(\mathrm{gmol}) /\left(\mathrm{bar}^{2} \cdot \mathrm{g} \cdot \mathrm{h}\right)$ \\
\hline $\mathrm{E}_{7}=34104 \mathrm{~J} / \mathrm{gmol}$ \\
\hline
\end{tabular}

The oxygen / carbon monoxide molar ratio is around 1-1.5. The operating temperature is $199^{\circ} \mathrm{C}$. Using an isothermal model for the reactor is not an appropriate consideration. As a proposal it is possible to divide the reactor in two or more stages with inter-cooling between them, so that the reactor comes close to the isothermal model, where there is greater conversion of carbon monoxide.
Table 5 - Results of Selective Oxidation Reactor

\begin{tabular}{|c|c|}
\hline \multicolumn{2}{|c|}{ Concentration of CO (ppm) } \\
\hline Inlet & Outlet \\
\hline 54 & 2 \\
\hline Selectivity for CO & $44 \%$ \\
\hline
\end{tabular}

\section{PROCESS EFFICIENCY AND PERFORMANCE}

The initial approach was to consider the effect of main operational variables, such as water/ ethanol molar ratio, steam reforming temperature and pressure on the chemical equilibrium. The system of reactions was studied with a mathematical modeling based on the following thermodynamic statements:

$$
\begin{aligned}
& \ln K_{e q}=-\Delta G^{0} /(R T) \\
& \frac{d \ln K_{e q}}{d T}=\frac{\Delta H^{o}}{R T^{2}}
\end{aligned}
$$

These equations allow evaluating equilibrium constant, molar fractions and reactions coordinates' dependence with the mentioned variables. A usual simplification is that for low pressure and high temperatures the vapour mixture is considered ideal.

$$
\begin{aligned}
& K_{e q}=\prod_{1}^{i} f_{i}^{v i} \frac{P}{P^{o}} \\
& f_{i}=y_{i} \phi_{i} \\
& \phi_{i}=1 \\
& f_{i}=y_{i}
\end{aligned}
$$

According to the first principle of thermodynamics, the following energy balance is considered:

$$
W_{e}-W_{b}-W_{c}+Q_{E}=\sum_{\text {inlet }} F_{i} h_{i}-\sum_{\text {oultet }} F_{i} h_{i}=\Delta H_{\text {system }}
$$

The pump and compressor efficiencies were both considered as 75\%. The electrical power of unit is equal to energy generated from hydrogen produced in the process. It is calculated through the following expression: 
$W_{e}=P C I_{H_{2}} \cdot F_{H_{2}} \cdot \eta_{\text {cell }}$

The fuel cell electrical efficiency is $45 \%$, based on common design values for low power systems. The nominal electrical power of the unit is $1 \mathrm{~kW}$. It was considered that the cell can handle with any amount of hydrogen with the same efficiency. It is possible to calculate the system power as the energy gap between the power generated in the unit minus it's electric energy consumption.

$W_{\text {system }}=P C I_{H_{2}} \cdot F_{H_{2}} \cdot \eta_{\text {cell }}-W_{b}-W_{c}$

Therefore, the efficiency is calculated by the following equation:

$\eta=\frac{W_{\text {system }}}{\sum_{\text {inlet }} F_{i} h_{i}-\sum_{\text {outlet }} F_{i} h_{i}}$

\section{PROCESS EXERGY}

Exergy of a thermodynamic system is the maximum work that can be obtained taking the system into equilibrium with the environment through the reversible process. In a real process (irreversible), there is a balance of work that is not feasible, which gives a measure of the irreversibility of the process. Several works were proposed in order to define exergy.

Dincer and Rosen (1999) defined exergy as the maximum work that can be produced by a system, matter or energy flow until it reaches the equilibrium with the environment reference. Differently from energy, exergy is not subject to conservation law (except for ideal processes, reversible), because it can be dissipated ("destroyed"), due to irreversibilities of any real process. The consumption of exergy during the process is proportional to the entropy created due to irreversibilities (Santos, 2007).

The exergy is similar to the Gibbs energy, but they have different meanings. The Gibbs energy is a state function of the system properties, however the exergy depends on pressure and temperature.

Szargut et al. (1988) reported the main characteristics and comparative between energy and exergy. This comparison can be seen in Table 5-1 (Santos, 2007):

Table 6 - Comparison between energy and exergy

\begin{tabular}{|c|c|}
\hline Energy & Exergy \\
\hline $\begin{array}{c}\text { Conservation of Energy (1st law of } \\
\text { thermodynamics). }\end{array}$ & $\begin{array}{c}\text { You may or may not be maintained (may be } \\
\text { destroyed by the irreversibility of the process) }\end{array}$ \\
\hline $\begin{array}{c}\text { It is a state function } \\
\text { It is a state function } \\
\text { any reference state. }\end{array}$ & $\begin{array}{c}\text { The reference state is imposed by } \\
\text { environment in which to vary. }\end{array}$ \\
\hline Can be transferred & Can be transferred \\
\hline $\begin{array}{c}\text { For ideal gas, does not depend on } \\
\text { pressure }\end{array}$ & $\begin{array}{c}\text { Always depends on the pressure } \\
\text { To reach an isobaric process } \\
\text { Increases with increasing temperature }\end{array}$ \\
\hline
\end{tabular}

The exergy analysis consists essentially in identificate and quantificate the irreversibilities of the system, this can be applied by using the exergy input (inputs) and output (product and waste) in the system and calculating efficiency exergy of the system. The exergetic analysis of a system allows to express the energetic limits of different process- es, such as technological, economic, environmental and social.

The exergetic function or exergy $\left(\mathrm{Ex}_{\mathrm{sp}}\right)$ takes into consideration the difference of concentration and chemical potential between chemical species, electric and electromagnetic effects, etc. So, the following equation can be used (Silveira et al., 2003): 


$$
e x_{\text {especie }}=e x_{T D}+e x_{K}+e x_{P}+e x_{C H}
$$

where $\mathrm{ex}_{\mathrm{TD}}$ is the amount related to thermodynamic equilibrium, the kinetic $\mathrm{ex}_{\mathrm{K}}$, $\mathrm{ex}_{\mathrm{P}}$ potential and $\mathrm{ex}_{\mathrm{CH}}$ to former chemist. These can be calculated as follow:

$$
e x_{T D}=\left(h_{i}-h_{o}\right)-T o\left(s_{i}-s_{o}\right)
$$

$e x_{C H}=e x_{Q}+R T o \ln \left(\frac{P_{i}}{P_{o}}\right)$

$e x_{c}=\frac{V_{1}^{2}}{2}(24)$

$e x_{P}=g z$

Where the subscript " $\mathrm{i}$ " indicates a thermodynamic property at final condition of process, the subscript "o" in the initial condition, $\mathrm{V}$ is the velocity of a body, "g" is the acceleration of gravity, "z" is the height axis, "ex ${ }_{Q}$ is the standard exergy chemical of each substance and "R" is the universal gas constant. Then the equation 1 can be written as follow:

$$
e x_{\text {especie }}=\left(h_{i}-h_{o}\right)-T o\left(s_{i}-s_{o}\right)+\frac{V_{1}^{2}}{2}+g z+e x_{Q}+R T o \ln \left(\frac{P_{i}}{P_{o}}\right)(26
$$

In the next table, are the standard exergy of the species involved in ethanol reforming
Table 7 - Chemical exergy of the considered species

\begin{tabular}{|c|c|}
\hline Specie & exCH $(\mathrm{kJ} / \mathrm{kg})$ \\
\hline Ethanol & 27765 \\
\hline Water & 480 \\
\hline Hidrogen & 117625 \\
\hline Carbon dioxide & 457 \\
\hline
\end{tabular}

The flow exergy of each species can be determined by exergy species multiplied by the mass flow of species in the process

$$
E x=(m)\left(e_{\text {especie }}\right)
$$

The exergy efficiency of a process, can be determined using the flow exergy of the species that enter and leave of a process by the following equation:

$$
\eta_{\text {exergética }}=\frac{E x_{H_{2}}}{\sum \dot{E} x_{\text {entrada }}-\left(\left(\sum \dot{E x_{\text {sai }}}\right)-\dot{E x_{H_{2}}}\right)}
$$

To calculate the exergy efficiency of steam reforming of ethanol was considered the overall reaction process. The properties values of the species involved in the calculation were obtained from the software used for simulation. The thermodynamic model used was UNIQUAC. The temperature for the process was regarded as 800 ${ }^{\circ} \mathrm{C}$ because this temperature is possible to consider a high degree of progress towards the overall reaction. The operating pressure of the reform is 5 bar. The following table shows the values of properties used in the calculation.

Table 8 - Enthalpy and entropy of the species involved

\begin{tabular}{|c|c|c|c|c|c|}
\hline Substância & $\begin{array}{c}\text { Massa }(\mathrm{kg} / \\
\mathrm{kmol})\end{array}$ & $\begin{array}{c}\mathrm{H}_{\mathrm{o}} \\
(\mathrm{kJ} / \mathrm{kmol})\end{array}$ & $\mathrm{S}_{\mathrm{o}}(\mathrm{kJ} / \mathrm{kmol} . \mathrm{k})$ & $\begin{array}{c}\mathrm{H}_{1} \\
(\mathrm{~kJ} / \mathrm{kmol})\end{array}$ & $\begin{array}{c}\mathrm{S}_{1}(\mathrm{~kJ} / \\
\mathrm{kmol} / \mathrm{k})\end{array}$ \\
\hline Etanol & 46 & $-278143,1$ & 282,6 & $-147548,8$ & 277,87 \\
\hline Água & 18 & $-284902,9$ & 188,7 & $-211863,3$ & 158,78 \\
\hline Hidrogênio & 2 & 0,0 & 130,6 & 22869,9 & 185,62 \\
\hline $\begin{array}{c}\text { Dióxido de } \\
\text { Carbono }\end{array}$ & 44 & $-393790,0$ & 213,7 & $-356752,6$ & 256,55 \\
\hline
\end{tabular}


The process has a high exergetic efficiency of $92 \%$.

\section{RESULTS AND DISCUSSION}

The unit is compact and has a $1 \mathrm{~kW}$ nominal power. The feed stream is $6 \mathrm{~mol} / \mathrm{h}$ of ethanol. The water/ethanol molar ratio defines the amount of make-up water that is necessary. The process yield and efficiency were evaluated.

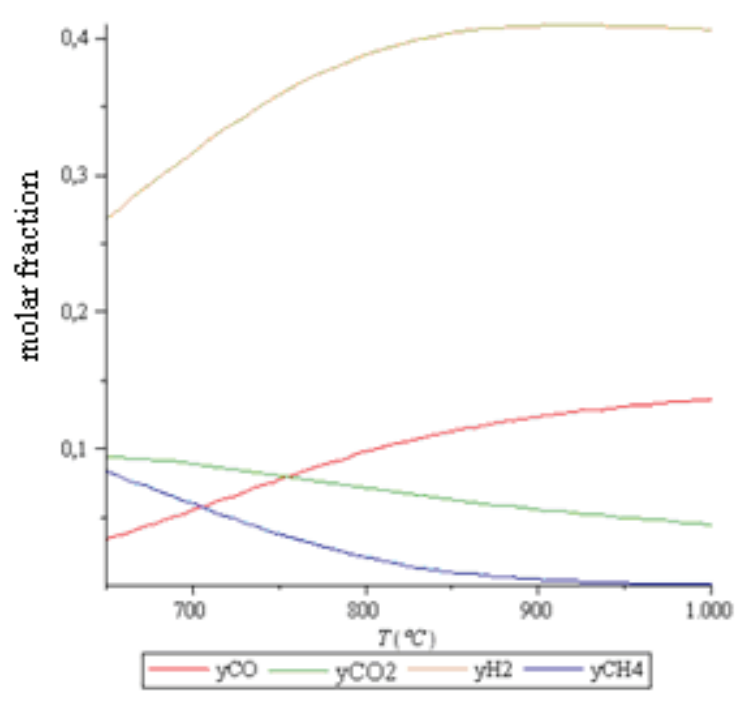

(a)

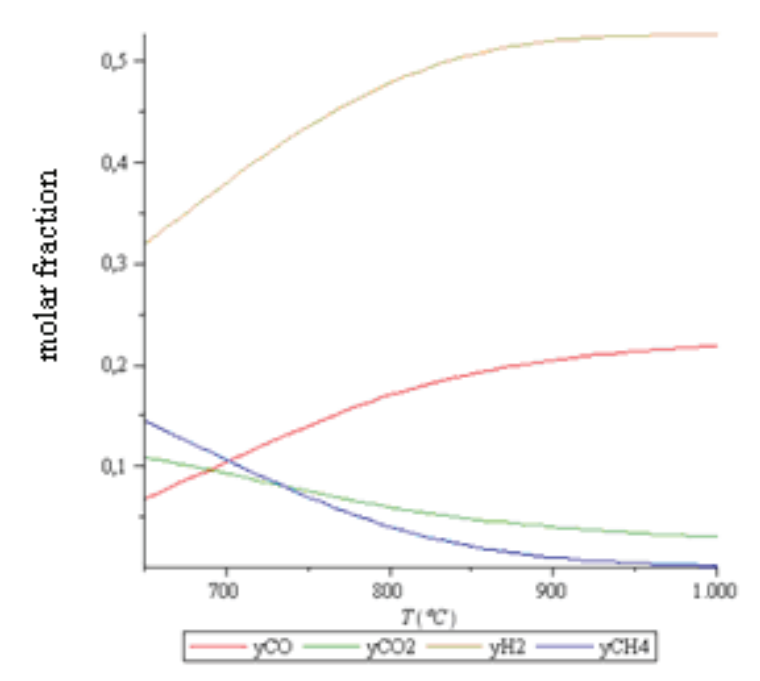

(b)

Figures 4 (a) and (b) - Components molar fractions in the chemical equilibrium (a) Operating pressure is $5 \mathrm{bar}$, Water/Ethanol molar ratio is 6 and (b) Operating pressure is 3 bar, Water/Ethanol molar ratio is 3 .

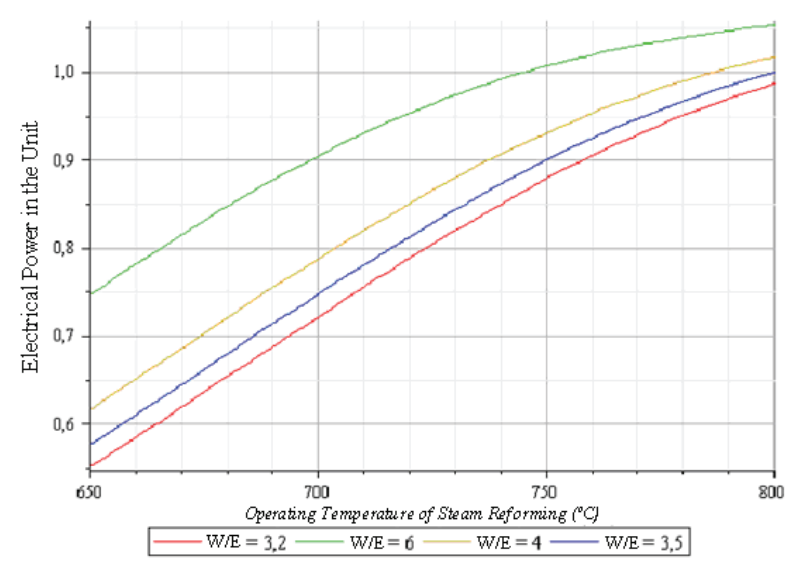

(a)

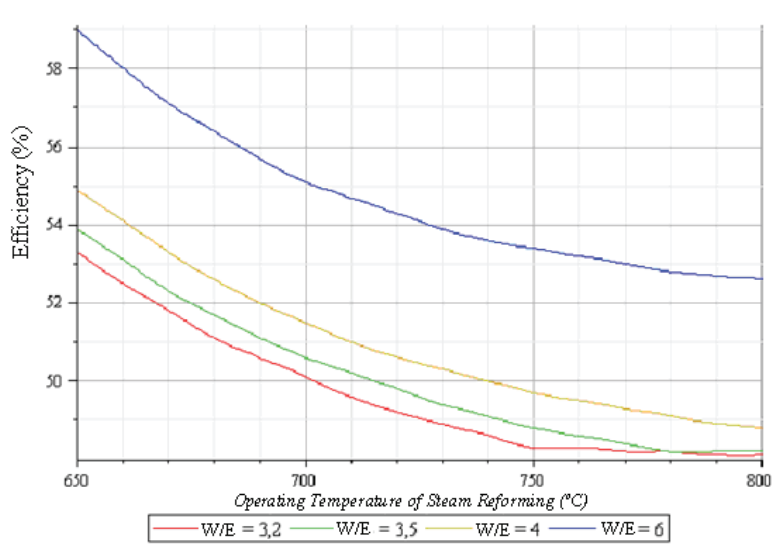

(b)

Figures 5 (a) and (b) - Electrical power generated (a) and efficiency (b) as a function of the steam reforming operating temperature for different Water/Ethanol molar ratios.

It is possible to observe an increase of hydrogen production by increasing the operating temperature of the reformer. Additionally, the effect of increasing the water / ethanol molar ratio shifts the chemical equilibrium for hydrogen production. The higher the molar ratio, the better is the result, while comparing at the same temperature. It is possible to achieve good hydrogen production by operating at low pressures, however, the fuel cell operating pressure doesn't allow low pressure reforming, unless there is a hydrogen compressing system at the of the process.

High operating temperatures minimizes the production of chemical intermediates such as methane but offers lower efficiencies. The option of high molar ratios of water / ethanol is used to reduce this effect and to improve efficiencies at a given temperature. This option in- 
creases the cost of unit, but makes the process more efficient. For an operating temperature exceeding $750^{\circ} \mathrm{C}$ and molar ratio water / ethanol equal to 6 , the system presents satisfactory efficiency of $53.5 \%$, where the power generated by the unit is around $1 \mathrm{~kW}$.

\section{PROCESS DESIGN}

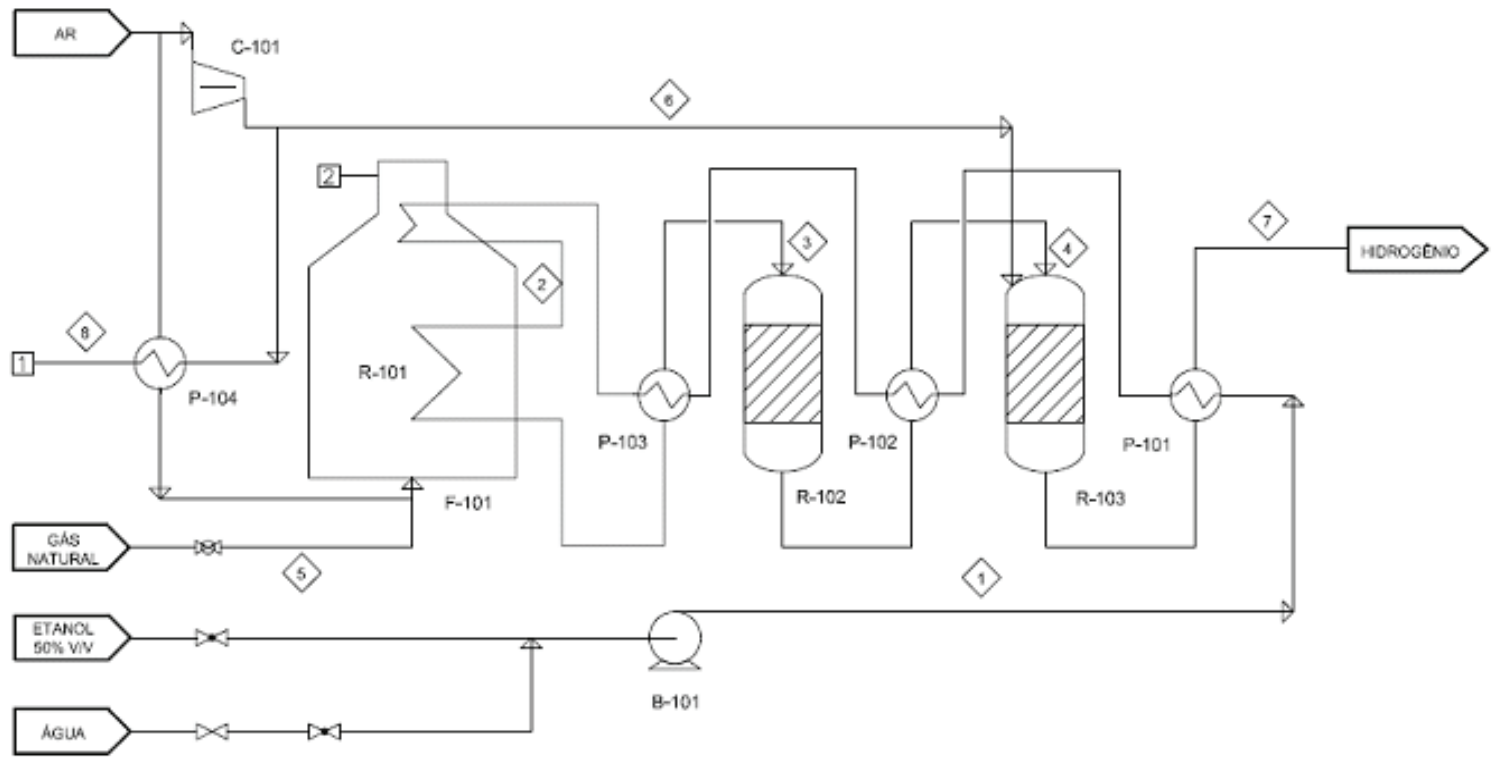

Figure 6 - Process flow diagram.

Table 9 - Mass balance and stream properties.

\begin{tabular}{|c|c|c|c|c|c|c|c|c|}
\hline Stream & 1 & 2 & 3 & 4 & 5 & 6 & 7 & 8 \\
\hline Molar (\%) & & & & & & & & \\
\hline $\mathrm{C}_{2} \mathrm{H}_{5} \mathrm{OH}$ & 14,2857 & 14,2857 & 0,0000 & 0,0000 & - & - & 0,0000 & - \\
\hline & - & - & 43,5217 & 51,8867 & - & - & 51,8669 & - \\
\hline $\mathrm{CO}$ & - & - & 8,3704 & 0,0054 & - & - & 0,0001 & - \\
\hline $\mathrm{H}_{2} \mathrm{O}$ & 85,7142 & 85,7142 & 37,9644 & 29,5994 & - & - & 29,5988 & - \\
\hline $\mathrm{O}_{2}^{2}$ & - & - & - & - & - & 21,0000 & 0,0000 & 21,0000 \\
\hline $\mathrm{CO}_{2}$ & - & - & 9,2311 & 17,5961 & 1,9802 & - & 17,5978 & - \\
\hline $\mathrm{CH}_{4}$ & - & - & 0,9124 & 0,9124 & 89,1089 & - & 0,9122 & - \\
\hline $\mathrm{N}_{2}$ & - & - & - & - & 2,9703 & 79,0000 & 0,0242 & 79,0000 \\
\hline $\mathrm{C}_{2} \mathrm{H}_{6}$ & - & - & - & - & 5,9406 & - & - & - \\
\hline $\begin{array}{l}\text { Molar flow } \\
(\mathrm{gmol} / \mathrm{h})\end{array}$ & 41,60 & 41,60 & 47,26 & 64,20 & 3,49 & 0,019 & 64,22 & 79,31 \\
\hline Vapour fraction & 0,00 & 1,00 & 1,00 & 1,00 & 1,00 & 1,00 & 1,00 & 1,00 \\
\hline $\begin{array}{l}\text { Molar mass (g/ } \\
\text { gmol) }\end{array}$ & 22,02 & 22,02 & 14,27 & 14,27 & 17,78 & 28,85 & 14,27 & 28,85 \\
\hline Density $\left(\mathrm{kg} / \mathrm{m}^{3}\right)$ & 945 & 1,29 & 1,64 & 1,82 & 4,36 & 3,67 & 3,11 & 4,82 \\
\hline Temperature $\left({ }^{\circ} \mathrm{C}\right)$ & 25 & 750 & 250 & 199 & 25 & 199 & 80 & 80 \\
\hline Pressure (bar) & 5 & 5 & 5 & 5 & 6 & 5 & 5 & 5 \\
\hline
\end{tabular}


Table 10 - Equipment list and main design parameters

Table 11 - Symbology

\begin{tabular}{|c|c|}
\hline B-101 & $\begin{array}{l}\text { ETHANOL PUMP } \\
\text { Power: 0,356 W } \\
\text { Efficiency: } 75 \%\end{array}$ \\
\hline C-101 & $\begin{array}{c}\text { AIR COMPRESSOR } \\
\text { Power: } 0,14 \mathrm{~kW} \\
\text { Adiabatic efficiency: } 75 \%\end{array}$ \\
\hline F-101 & $\begin{array}{c}\text { REFORMER } \\
\text { Nominal capacity: } 0,7 \mathrm{~kW} \\
\text { Estimated sizes: } 100 \text { x } 100 \text { x } 150(\mathrm{~cm})\end{array}$ \\
\hline P-101 & $\begin{array}{l}\text { HEAT EXCHANGER1 } \\
\text { Heat transfer: } 0,224 \mathrm{~kW} \\
\text { LMTD: } 40,92^{\circ} \mathrm{C}\end{array}$ \\
\hline P-102 & $\begin{array}{l}\text { HEAT EXCHANGER } 2 \\
\text { Heat transfer: } 0,0309 \mathrm{~kW} \\
\text { LMTD: } 82,10^{\circ} \mathrm{C}\end{array}$ \\
\hline P-103 & $\begin{array}{l}\text { HEAT EXCHANGER } 3 \\
\text { Heat transfer: } 0,344 \mathrm{~kW} \\
\text { LMTD: } 246,12^{\circ} \mathrm{C} \\
\end{array}$ \\
\hline P-104 & $\begin{array}{l}\text { HEAT EXCHANGER } 4 \\
\text { Heat transfer: } 0,0492 \mathrm{~kW} \\
\text { LMTD: } 103,38^{\circ} \mathrm{C}\end{array}$ \\
\hline $\mathrm{R}-101$ & $\begin{array}{c}\text { STEAM REFORMING REACTOR } \\
\text { (PFR) } \\
\text { Fixed bed: Nickel catalyst. Volume: } \\
200 \mathrm{~mL} \\
\text { Operating temperature: } 750^{\circ} \mathrm{C} \\
\text { Operating pressure: } 5 \text { bar }\end{array}$ \\
\hline R-102 & $\begin{array}{c}\text { SHIFT REACTOR (PFR) } \\
\text { Fixed bed: } \mathrm{CuZnO} / \mathrm{Al}_{2} \mathrm{O}_{3} \text {. Volume: } \\
100 \mathrm{~mL} \\
\text { Operating temperature: } 250^{\circ} \mathrm{C} \\
\text { Operating pressure: } 5 \mathrm{bar}\end{array}$ \\
\hline R-103 & $\begin{array}{l}\text { SELECTIVE OXIDATION REACTOR } \\
\text { (PFR) } \\
\text { Fixed bed: Pt-Fe/ } \mathrm{Al}_{2} \mathrm{O}_{3 .} \text { Volume: } 80 \mathrm{~mL} \\
\text { Operating temperature: } 199^{\circ} \mathrm{C} \\
\text { Operating pressure: } 5 \text { bar }\end{array}$ \\
\hline
\end{tabular}

$A_{i}-$ pre-exponential factor

$\mathrm{W} / \mathrm{E}$ - water / ethanol molar fraction exCH - chemical exergy $[\mathrm{kJ} / \mathrm{kg}]$ $\mathrm{f}$ - fugacity

$\varnothing-$ fugacity coefficient

$\mathrm{F}_{\mathrm{i}}$ - component i molar flow $[\mathrm{mol} / \mathrm{h}]$

$\mathrm{h}_{\mathrm{i}}$ - component i molar enthalpy [kWh/ $\mathrm{mol}]$

$\mathrm{i}$ - component formula or reaction number

$\Delta \mathrm{H}$ - enthalpy difference $[\mathrm{kJ} / \mathrm{mol}]$

$\Delta \mathrm{G}-$ Gibbs free energy difference $[\mathrm{kJ} /$ mol]

$\mathrm{k}_{\mathrm{i}}$ - reaction I kinetic coefficient at $\mathrm{T}$

$\mathrm{K}_{\mathrm{i}}$ - component i equilibrium adsorption constant

LMTD - logarithmic mean temperature difference

$\eta$ - efficiency

$\mathrm{P}$ - operating pressure [bar]

Po - standard pressure [ $1 \mathrm{bar}$ ]

$\mathrm{PCI}_{\mathrm{H} 2}-$ hydrogen low heat value $[241,83$ $\mathrm{kJ} / \mathrm{mol}]$

PEMFC - proton exchange membrane fuel cell

PFR - plug flow reactor

$\mathrm{Q}_{\mathrm{FC}}$ - fuel cell heat $[\mathrm{kW}]$

$\mathrm{r}$ - reaction rate

- density $\left[\mathrm{kg} / \mathrm{m}^{3}\right]$

$\mathrm{T}$ - operating temperature $[\mathrm{K}]$

$\mathrm{W}_{\mathrm{b}}$ - pump power [kW]

$\mathrm{W}_{\mathrm{c}}$ - compressor power $[\mathrm{kW}]$

$\mathrm{W}_{\mathrm{e}}$ - power generated $[\mathrm{kW}]$ 


\section{ENVIRONMENTAL ISSUES}

The evident need to reduce consumption of fossil fuels associated with the development of technologies that use renewable resources for electric energy generation, has attracted much interest from researchers in technologies for hydrogen production.

The incorporation of these technologies in urban centers has been well regarded since its use is not characterized by the emission of greenhouse gases.

Currently, one of the major problems is the production of hydrogen in a sustainable manner. Because its production process demands great amounts of energy, which should always be sourced from a sustainable source in order to provide conditions that may lead to the hydrogen economy. Thus, one of the best tools to get a complete overview of the process would be through the analysis of the life cycle for hydrogen fuel, in other words, the amount of $\mathrm{CO} 2$ emitted in the production of ethanol and the process of reforming of ethanol.

These calculations were made by LORENZI, 2009 that reached the following values: for the reform of ethanol were produced $76.4 \mathrm{~g}$ of $\mathrm{CO}_{2}$ per MJ of hydrogen produced, while reforming of natural gas were produced 57.6 g/MJ. From these values, the conclusion to be drawn is that the reform of natural gas is more advantageous compared to ethanol, however, the $\mathrm{CO}_{2}$ emitted by the process of ethanol reforming is consumed during the growth of sugar cane.

In this case, we consider the emission of $\mathrm{CO}_{2}$ in the process of ethanol steam reforming as null, taking this process to a level of extremely low environmental impact.

\section{REFERENCES}

ANDRADE, L. M. Reforma a vapor e oxidativa do etanol para a produção de hidrogênio utilizando catalisadores de Ródio suportados em alfaalumina, óxido de Cério, e óxido de cério-alfaalumina. São Paulo: USP, 2007.

AMADEO, N.; LABORDE, M.; MAS, V.; BERGAMINI, M. L.; BARONETTI, G. A Kinetic Study of Ethanol Steam Reforming Using a Nickel Based Catalyst. Original Paper - Springer Science+Business. 2008.
CAMARGO, J.C. O etanol como fonte de hidrogênio para células a combustível na geração distribuída de energia elétrica. Campinas, SP. 2004.

CAVALLARO, S. Ethanol Steam Reforming on Rh/Al2O3 Catalysts Energy Fuels, v. 14, p. 1195-1199, 2000.

CHOI, Y.; STENGER, H. Kinetics, simulation and insights for co selective oxidation in fuel cell applications. journal of power sources, 129:246254, 2004.

DAVIES, J.; LIHOU, D. Optimal design of methane steam reformer. Chem. Proc. Eng., 52:71-80, 1971.

GEORGOPOULOUS, N. Application of a decomposition strategy to the optimal sythesis/design and optimization of a fuel cell based total energy system. Virginia Polytechnic Institute and State Univeristy, 2002

GIUNTA, P.; MOSQUERA, C.; AMADEO, N.; LABORDE, M. Simulation of a hydrogen production and purification system for a PEM fuelcell using bioethanol as raw material. Journal of Power Sources, v.164, p. 336-343, 2007.

LORENZI, C. E. Impactos Ambientais e Energéticos Provocados Pela Substituição de Motores de Combustão Interna por Células a Combustível em Veículos Automotores, São Caetano do Sul. 2009.

RAMPE, T. Entwicklung eines BioethanolDampfreformers zur Erzeugung von Wasserstoff für den Einsatz in einem PEM-BrennstoffzellenBHKW. Universität Duisburg-Essen, 2004.

ROSTRUP-NIELSEN, J.R. Syngas in perspective. Catalysis Today. n. 71, p. 243-247, 2002.

SAHOO, D. R.; SANJAY, S.; PANT, K. Kinetic modeling of steam reforming of etanol for the production of hydrogen over $\mathrm{Co} / \mathrm{Al} 2 \mathrm{O} 3$. Chem. Eng. J., v.125, p.139-147, 2007.

SMITH, J.M.; VAN NESS, H. C. Termodinâmica da Engenharia Química. São Paulo: LTC, 5ª edição, SP, 1987. 